\title{
Efektifitas Pemanfaatan Teknologi Informasi dan Komunikasi terhadap Tata Persuratan Elektronik (Paperless Office System) (Studi Kasus: Universitas Islam Negeri Raden Fatah Palembang)
}

\author{
Awang Sugiarto \\ awangsugiarto@radenfatah.ac.id
}

\section{Pusat Teknologi Informasi dan Pangkalan Data, UIN Raden Fatah Palembang}

Diterima: 17 April 2020 | Direvisi: 25 Mei 2020 | Disetujui: 29 Mei 2020

(C) 2020 Program Studi Sistem Informasi Fakultas Sains dan Teknologi,

Universitas Islam Negeri Raden Fatah Palembang, Indonesia

Abstrak: Penelitian ini bertujuan untuk mengetahui seberapa efektif dan efisiennya tata persuratan pada kampus Universitas Islam Negeri Raden Fatah Palembang setelah pemanfaatan teknologi informasi dan komunikasi secara elektronik (paperless office system) yang berbasis online dalam memproses pelayanan surat masuk. Pemanfaatan teknologi informasi dan komunikasi dalam tata persuratan merupakan suatu manajemen tata persuratan suatu instansi dalam memanfaatkan teknologi informasi berupa media komputer, internet atau me dia lainnya baik menggunakan sistem secara manual maupun secara elektronik. Pokok pembahasan dalam penelitian ini adalah seberapa efektifnya pemrosesan pelayanan surat masuk dengan sistem elektronik serta kendala-kendala yang dihadapi dalam menerapkan kedua sistem tersebut pada manajemen persuratan. Hasil dari penelitian ini, Universitas Islam Negeri Raden Fatah Palembang dalam pemanfaatan teknologi informasi dan komunikasi secara elektronik sudah berjalan lebih lancar dan sangat efektif, khususnya dalam pemrosesan surat masuk. Sedangkan untuk pengurusan surat keluar belum dapat diterapkan karena sistem aplikasi belum sesuai dengan prosedur sehingga pelaksanaannya masih secara manual.

Kata Kunci: Teknologi Informasi, e-office, paperless office system

\begin{abstract}
This research aims to determine how effective and efficient correspondence management is at the Raden Fatah State Islamic University Palembang campus after the use of online-based information and communication technology (paperless office system) in processing incoming mail services. Utilization of information and communication technology in correspondence system is an agency's correspondence management in utilizing information technology in the form of computer, internet or other media, either manually or electronically. The subject matter of this research is how effective is the processing of incoming mail services using electronic systems and the constraints faced in implementing the two systems in correspondence management. The results of this study indicate that the Raden Fatah State Islamic University of Palembang in the use of electronic information and communication technology has run more smoothly and is very effective, especially in processing incoming mail. Meanwhile, the outgoing mail management cannot be implemented because the application system is not in accordance with the procedure so that the implementation is still manual. Keywords: Information Technology, e-office, peperless office system
\end{abstract}

\section{PENDAHULUAN}

Bekerja di kantor sangat diminati bagi semua orang, kantor juga menjadi pusat kegiatan karyawannya dalam membantu pimpinan, memberikan informasi, menghimpun informasi sampai mendistribusikan informasi. Tugas kantor adalah melaksanakan pekerjaan bersifat administratif yang menyiapkan data dan informasi untuk kepentingan organisasi dan kepentingan umum (Sugiarto \& Wahyono, 2014). 
Teknologi merupakan sebuah kebutuhan yang sangat penting dalam era teknologi saat ini, perkembangan teknologi komputer pada saat ini sangatlah penting dalam hal layanan publik (Khairil, 2012). Dalam bahasa sehari-hari kata teknologi berdekatan artinya dengan istilah tata cara. Sedangkan kata informasi dapat diartikan sebagai berita yang mengandung maksud tertentu. Manusia memiliki pengetahuan dan pengalaman yang selalu ingin dibagikan pada orang lain. Pengalaman atau pengetahuan yang dikomunikasikan kepada orang lain tersebut merupakan pesan atau informasi. Jadi, pesan atau informasi menuntut adanya kehadiran pihak lain. Kata komunikasi berasal dari bahasa latin communicare yang bermakna berbagi atau menyampaikan pesan, berita, informasi dan perasaan kepada orang lain (Parsaorantua et al., 2017). Jadi dapat disimpulkan bahwa pengertian teknologi informasi merupakan tata cara atau sistem atau sebuah media yang digunakan untuk menyampaikan pesan baik itu untuk memperoleh suatu data/informasi maupun memberikan informasi kepada orang lain serta dapat digunakan untuk alat berkomunikasi baik satu arah ataupun dua arah (Nurhadi \& Kurniawan, 2017).

Seluruh instansi pemerintah sekarang ini baik itu pemerintahan pusat maupun instansi pemerintahan daerah telah dan memanfaatkan Teknologi Informasi dan Komunikasi (TIK) sebagai pendukung dalam melaksanakan tugas pokok dan fungsi (Tupoksi). Namun seiring dengan perjalanan dan perkembangannya, Teknologi Informasi dan Komunikasi belum dimanfaatkan secara maksimal untuk meningkatkan administrasi perkantoran dan sebagian masih menggunakan sistem manual (Sulistiyono \& Yasin, 2016).

Tata kelola pemerintah (management) dan teknologi akan membantu pemerintah untuk meningkatkan kualitas di bidang pelayanan publik. Elektronik Government merupakan penggunaan teknologi informasi yang dapat meningkatkan hubungan antara pemerintah dan pihak-pihak lain (masyarakat) (Supriyanto, 2016).

E-government diperlukan karena jawaban atas perubahan lingkungan strategis yang menuntut administrasi negara yang efektif, efisien, berorientasi pada publik, transparan dan akuntabel. Menyadari akan besarnya manfaat E-government, pemerintah Indonesia sejak tahun 2003 telah mengeluarkan kebijakan tentang penerapan E-government dalam bentuk Instruksi Presiden Nomor 3 tahun 2003. Dalam E-government dikenal sebuah layanan untuk mendukung kegiatan perkantoran khususnya administrasi dengan nama e-office (Sulistiyono \& Yasin, 2016).

Perkembangan teknologi yang semakin maju memudahkan manusia dalam melakukan aktivitasnya, misalnya dalam pengelolaan dokumen yang pada mulanya hanya dimasukkan dalam lemari arsip kini berkembang dalam sistem manajemen dokumen berbasis digital. Dengan demikian dibutuhkan adanya suatu sistem informasi yang dapat membantu dalam pengembangan mutu maupun kinerja dari sebuah lembaga atau instansi. Pada saat ini banyak lembaga mulai menggunakan sistem informasi untuk memperoleh informasi yang digunakan oleh berbagai level. Para staf menggunakan informasi dari komputer untuk mempercepat pelayanan kepada pelanggan atau untuk kepentingan internal maupun manajemen (Reja \& Suban, 2016).

Dengan perkembangan teknologi yang semakin pesat mengakibatkan keperluan administrasi perkantoran, seperti dalam proses pengarsipan, dokumentasi dan surat menyurat yang sering dilakukan dalam lingkungan perkantoran menjadi lebih efektif dan efisien. Teknologi informasi yang dapat mendukung kegiatan tersebut diantaranya yaitu penerapan $e$ office (Herdiana \& Marsofiyati, 2019).

E-office sebagai salah satu hasil dari pekembangan teknologi tentunya akan membantu pegawai di kantor dalam menyelesaikan tugas-tugas mereka. Tidak hanya pegawai, tetapi para pemimpin pun juga akan ikut menikmati hasilnya misalnya menghasilkan laporan yang dapat digenerate dengan cepat berdasarkan data terpadu yang ada didalam sistem $e$-office. Sistem $e$ office selain meminimalisasi penggunaan kertas (paperless), e-office juga mempermudah penyimpanan dan pengolahan data di dalam suatu kantor karena data menjadi terpusat (centralized) dengan bantuan database sehingga data yang ada akan saling terhubung dan

Volume 6, Nomor 1, Juni 2020 
menjadi kesatuan utuh yang dapat memberikan informasi bagi pegawai kantor (Mulyono, 2018).

Perkembangan teknologi di era revolusi industri 4.0 membawa kemudahan dan pergeseran dalam berbagai hal, semua ruang kehidupan bertransformasi menjadi digital, baik instansi pemerintah maupun swasta. Lebih dari itu, Paperless Office System dibuat bukan hanya dengan tujuan sekedar pengurangan pemakaian kertas, tetapi paperless office system membentuk budaya baru, yang menuntut penggunaan perangkat digital yang berada pada semua lini proses bisnis suatu instansi. Berikut ini manfaat dari paperless office system, antara lain:

1. Meningkatkan produktivitas, efektifitas dan efisiensi.

2. Memperlancar Komunikasi dan Kemudahan kolaborasi.

3. Mengurangi biaya operasional.

4. Peningkatan keamanan.

5. Ramah lingkungan, serta

6. Menjadikan pekerjaan kantor sebagai aktivitas yang tidak membosankan.

Universitas Islam Negeri Raden Fatah Palembang yang merupakan suatu lembaga pemerintah yang memberikan pelayanan di dunia pendidikan tinggi memandang bahwa Teknologi Informasi dan Komunikasi merupakan suatu keniscayaan. Univeristas Islam Negeri Raden Fatah Palembang menjadikan teknologi informasi dan komunikasi bagian terpenting dalam melaksanakan reformasi birokrasi sehingga pemanfaatannya perlu penekanan dan harus dapat memberikan nilai tambah dalam tata kelola administrasi pemerintahan.

Berdasarkan standar proses sebuah surat masuk ke instansi, surat di terima di bagian administrasi tata usaha, di agendakan pada buku kendali kemudian diteruskan ke pimpinan sesuai tujuan surat sampai dengan proses penyelesaian akhir maksud dan tujuan surat akan membutuhkan waktu yang tidak bisa di pastikan atau dapat memakan waktu berhari-hari, menyebabkan layanan terhadap stakeholder menjadi sering terhambat. Seringnya terhambatnya inilah menjadi serius ketika suatu instansi pelayanan publik tidak dapat memberikan kepastian layanan. Pemrosesan surat masuk sangat tergantung pada kehadiran pimpinan, kehadiran pimpinan merupakan faktor utama dalam pemberian layanan dalam memberikan perintah, dimulai dari pimpinan tertinggi maupun pimpinan setingkat di bawahnya. Jam kerja yang sangat terbatas dengan hanya tujuh setengah jam dalam sehari membuat tingkat efektifitas pemrosesan surat menjadi sedikit, berdampak pada penyelesaian pekerjaan atau pemberian layanan kepada stakeholder.

\section{METODOLOGI PENELITIAN}

Penelitian ini menggunakan metode analisis dengan pendekatan kualitatif dengan menggunakan metode deskriptif dengan tujuan untuk mengetahui tingkat efektifitas pemanfaatan paperless office system atau sistem informasi perkantoran yang berbasis web.

\subsection{Metode Penelitian Deskriptif}

Penelitian deskriptif merupakan penelitian yang berusaha mendeskripsikan suatu gejala peristiwa dan kejadian yang terjadi pada saat sekarang, dimana peneliti berusaha memotret peristiwa dan kejadian yang menjadi pusat perhatian untuk kemudian digambarkan sebagaimana adanya. Metode penelitian deskriptif digunakan untuk memecahkan masalah sekaligus menjawab permasalahan yang terjadi pada masa sekarang. Dilakukan dengan menempuh langkah-langkah pengumpulan data, klasifikasi dan analisis atau pengolahan data (Sugiyono, 2013).

\subsection{Pendekatan Kualitatif}

Pendekatan kualitatif adalah untuk mengungkapkan atau memperoleh informasi dari data penelitian secara menyeluruh, luas dan dalam. Penelitian kualitatif merupakan penelitian yang lebih mengutamakan pada masalah proses dan makna/persepsi, di mana penelitian ini 
diharapkan dapat mengungkap berbagai informasi kualitatif dengan deskripsi-analisis yang teliti dan penuh makna, yang juga tidak menolak informasi kuantitatif dalam bentuk angka maupun jumlah. Pada tiap-tiap obyek akan dilihat kecenderungan, pola pikir, ketidakteraturan, serta tampilan perilaku dan integrasinya sebagaimana dalam studi kasus genetik (Muhadjir, 1996).

\subsection{Analisis Alur Surat Masuk}

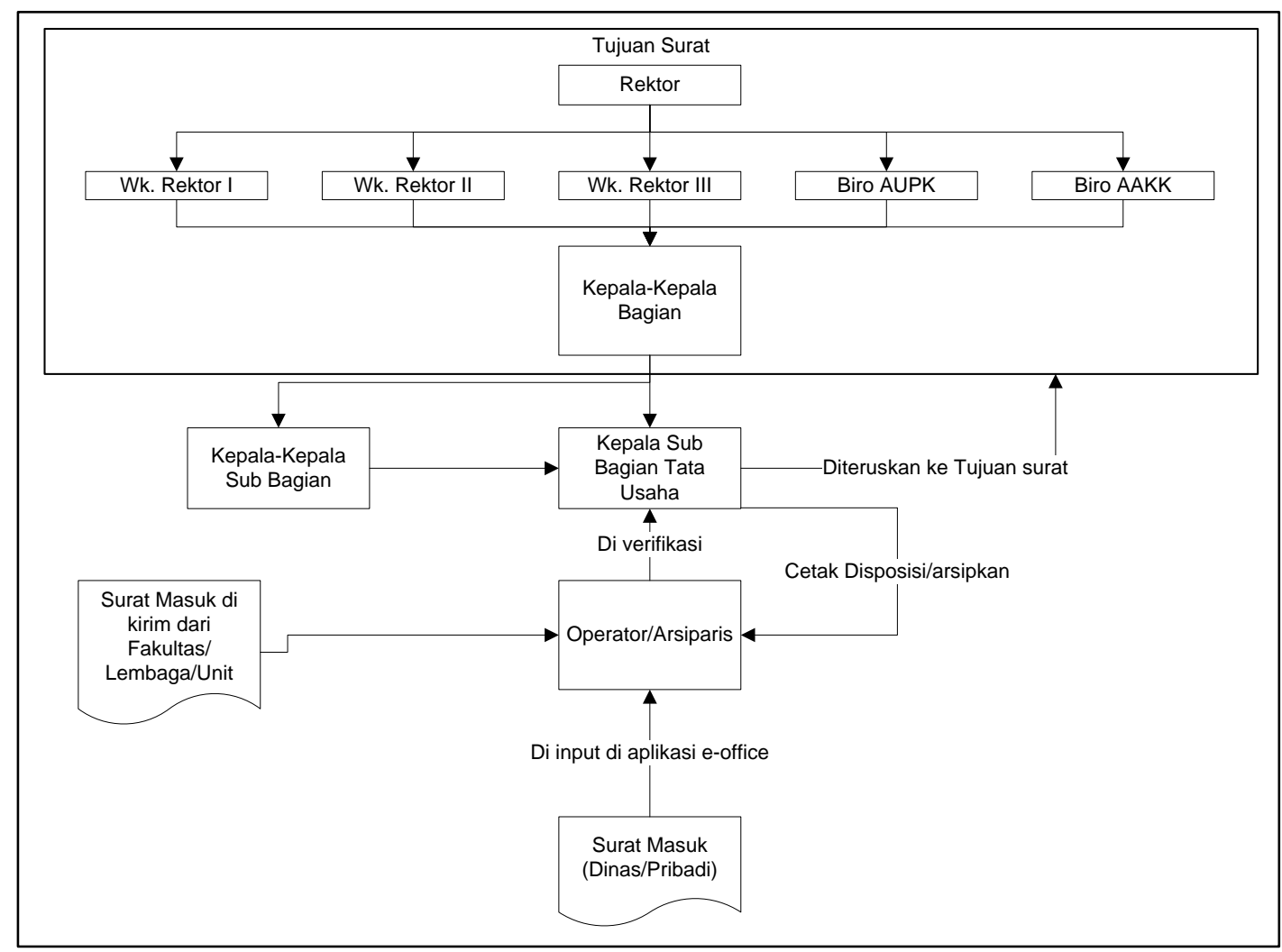

Gambar 1 Alur Surat Masuk di Rektorat

Kampus UIN Raden Fatah Palembang memiliki 2 (dua) kategori surat masuk, yaitu surat masuk internal dan surat masuk eksternal. Surat masuk internal merupakan surat yang masuk dari Fakultas, lembaga atau unit-unit yang ada di dalam lingkungan UIN Raden Fatah Palembang. Sedangkan surat masuk eksternal merupakan surat yang masuk dari luar lingkungan UIN Raden Fatah Palembang, misalnya surat pribadi dari masyarakat atau dari instansi di luar UIN Raden Fatah Palembang.

Surat masuk internal maupun eksternal di kampus UIN Raden Fatah Palembang melalui satu pintu, yaitu melalui Bagian Umum yang menjadi tugas dari Sub Bagian Tata Usaha. Pegawai atau arsiparis atau operator pada bagian Sub Bag Tata Usaha menginput detail surat masuk ke dalam sistem, mulai dari nomor, perihal, tanggal, penandatanganan dan tujuan surat. Surat yang telah diinput tersebut secara otomatis masuk ke akun Kepala Subbag Tata Usaha untuk diketahui dan verifikasi apakah surat masuk tersebut layak di teruskan atau tidak.

Setelah di setujui oleh Kepala Subbag Tata Usaha, surat masuk ke akun pimpinan sesuai tujuan surat yang di input oleh operator secara otomatis. Pimpinan kemudian memberikan disposisi kepada bawahan secara berjenjang sesuai struktur organisasi di UIN Raden Fatah Palembang. Proses yang dilakukan oleh sistem ini berbasis online, pimpinan dapat memproses surat masuk ke akun mereka tanpa dibatasi oleh kehadiran pimpinan di ruang kerja. Pimpinan dapat memproses surat saat sedang mobile atau sedang dalam keadaan tugas di luar kota maupun di luar jam kerja. 
Berdasarkan pengamatan penulis, sebelum pemanfaatan teknologi informasi atau paperless system, surat masuk di kampus UIN Raden Fatah Palembang sudah melalui satu pintu, yaitu melalui Bagian Umum yang menjadi tugas dari Sub Bagian Tata Usaha. Pegawai pada Subbag Tata Usaha mencatat surat masuk ke dalam buku agenda surat, kemudian disampaikan ke Kepala Sub Bagian Tata Usaha untuk di verifikasi arah tujuan surat. Surat yang telah di setujui oleh kepala Sub Bagian Tata Usaha di antar langsung oleh petugas ke bagian resepsionis yang melayani pimpinan. Surat tidak dapat proses oleh pimpinan ketika pimpinan sedang tidak berada di ruang kerja, surat masuk akan terus bertambah dan menyebabkan terjadi penumpukan jika pimpinan lama meninggalkan tempat kerja atau sedang tugas di luar kantor. Dengan menumpuknya surat di meja pimpinan mengakibatkan layanan perkantoran menjadi terlambat.

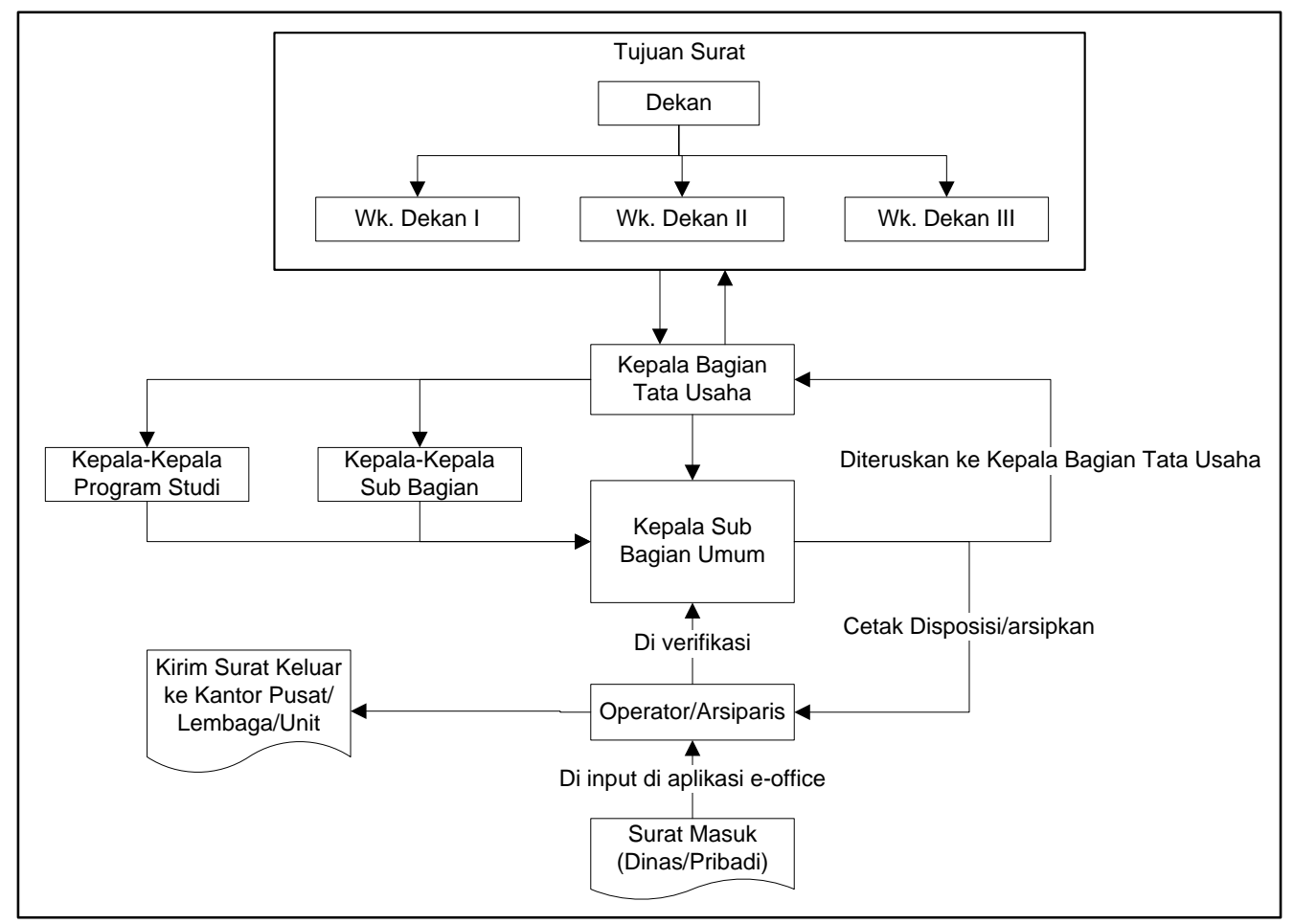

Gambar 2 Diagram Gambar Alur Surat Masuk di Fakultas

Fakultas di lingkungan UIN Raden Fatah Palembang juga memiliki 2 (dua) kategori surat masuk, yaitu surat masuk internal dan surat masuk eksternal. Surat masuk internal merupakan surat yang masuk dari Rektorat, Fakultas, lembaga atau unit-unit yang ada di dalam lingkungan UIN Raden Fatah Palembang. Sedangkan surat masuk eksternal merupakan surat yang masuk dari luar lingkungan UIN Raden Fatah Palembang.

Surat masuk internal maupun eksternal di fakultas-fakultas UIN Raden Fatah Palembang melalui satu pintu, yaitu melalui Bagian Tata Usaha yang menjadi tugas dari Sub Bagian Umum. Pegawai atau arsiparis atau operator pada bagian Subbag Umum menginput nomor, perihal, tanggal, penandatanganan dan tujuan surat ke dalam sistem. Surat yang telah diinput tersebut secara otomatis masuk ke akun Kepala Subbag Umum untuk diketahui dan verifikasi apakah surat masuk tersebut layak di teruskan atau tidak.

Setelah disetujui oleh Kepala Subbag Umum, surat masuk ke akun pimpinan sesuai tujuan surat yang di input oleh operator secara otomatis. Pimpinan kemudian memberikan disposisi kepada bawahan secara berjenjang sesuai struktur organisasi di UIN Raden Fatah Palembang. Proses yang dilakukan oleh sistem ini berbasis online, pimpinan dapat memproses surat masuk ke akun mereka tanpa dibatasi oleh kehadiran pimpinan di ruang kerja. Pimpinan dapat 
memproses surat saat sedang mobile atau sedang dalam keadaan tugas di luar kota maupun di luar jam kerja.

Berdasarkan hasil pengamatan, sebelum pemanfaatan teknologi informasi atau paperless system, surat masuk di kampus UIN Raden Fatah Palembang sudah melalui satu pintu, yaitu melalui Bagian Umum yang menjadi tugas dari Sub Bagian Tata Usaha. Pegawai pada Subbag Tata Usaha mencatat surat masuk ke dalam buku agenda surat, kemudian disampaikan ke Kepala Sub Bagian Tata Usaha untuk di verifikasi arah tujuan surat. Surat yang telah di setujui oleh kepala Sub Bagian Tata Usaha di antar langsung oleh petugas ke bagian resepsionis yang melayani pimpinan. Surat tidak dapat proses oleh pimpinan ketika pimpinan sedang tidak berada di ruang kerja, surat masuk akan terus bertambah dan menyebabkan terjadi penumpukan jika pimpinan lama meninggalkan tempat kerja atau sedang tugas di luar kantor. Dengan menumpuknya surat di meja pimpinan mengakibatkan layanan perkantoran menjadi terlambat.

Paperless system UIN Raden Fatah Palembang yang beralamat pada http://eoffice.radenfatah.ac.id/ merupakan layanan yang diterapkan oleh kampus UIN Raden Fatah Palembang sejak bulan Mei 2019. Penggunaan sistem ini tergolong sederhana dan mudah, semua unsur pimpinan mulai dari yang terendah hingga pimpinan tertinggi memiliki akun sistem masing-masing. Sistem ini di buat secara berjenjang sesuai dengan struktur organisasi dari UIN Raden Fatah Palembang, pimpinan tertinggi tidak dapat mendisposisikan surat langsung ke pimpinan terendah. Pimpinan hanya dapat mendisposisikan surat ke pimpinan satu tingkat dibawahnya.

Paperless system UIN Raden Fatah Palembang dapat di akses dimana saja, dikarenakan sistem ini sudah berbasis online, serta dapat di akses melalui komputer atau $P C$, laptop/notebook, bahkan melalui smartphone dan semua sistem operasi, contohnya Microsoft Windows, mac OS maupun Linux.

Paperless system UIN Raden Fatah Palembang memberikan notifikasi atau pemberitahuan yang menandakan ada pesan masuk atau surat masuk. Pemberitahuan atau notifikasi dapat terlihat ketikan user membuka dan login ke sistem. Pemberitahuan icon berkedip-kedip untuk menandakan ada surat masuk. Sistem ini belum memberikan pemberitahuan secara visual atau suara. Sebagai pemberitahuan untuk memberi peringatan, penerima surat akan menerima notifikasi melalui aplikasi pihak ketiga yaitu pesan dari aplikasi Telegram.

Paperless system UIN Raden Fatah Palembang ini juga telah memberikan fitur tambahan, jika pimpinan hanya membaca saja surat tanpa memberikan disposisi, operator dapat mengaktifkan kembali surat tersebut dan memberitahukan bahwa surat tersebut belum ada disposisi.

Paperless system UIN Raden Fatah Palembang ini memberikan kemudahan bagi bagian Umum atau Tata Usaha untuk melihat laporan surat masuk dan surat keluar, laporan harian, laporan mingguan dan laporan bulanan. Bagian Umum atau Tata Usaha dapat mengecek surat yang belum di selesaikan oleh pimpinan dan surat yang telah diselesaikan oleh pimpinan.

\section{HASIL DAN PEMBAHASAN}

Penggunaan layanan aplikasi e-office sangat membantu pimpinan dan pegawai dalam menyelesaikan kegiatan pengelolaan arsip, membuat surat, dan lainnya sehingga pimpinan dan pegawai lebih cepat dan tepat waktu dalam menyelesaikan pekerjaannya. Skema dan proses paperless office system yang diterapkan di Universitas Islam Negeri Raden Fatah Palembang dapat bekerja secara optimal dan dapat memberikan kemudahan kepada pimpinan dan karyawan sehingga membantu dalam efektivitas dan efisiensi waktu serta dapat meningkatkan produktivitas pegawai khususnya pimpinan. Meningkatnya produktivitas tersebut dapat dilihat dari kinerja pegawai yang semakin hari semakin baik dan mampu menyelesaikan tugasnya sesuai waktu yang telah ditentukan. 
Pemanfaatan paperless office system ini dapat membantu mengurangi penggunaan kertas yang banyak serta menghindari penumpukan-penumpukan berkas di meja pimpinan. Surat yang diinput ke dalam sistem yang sudah di lengkapi histori disposisi dapat di jadikan sebagai arsip digital. Dengan adanya arsip digital, akan memudahkan pencarian dokumen surat di masa lampau.

Dilihat dari hasil pengamatan, pemanfataan paperless office system pada kampus Universitas Islam Negeri Raden Fatah Palembang ini di analisis berdasarkan pengamatan tingkat keefektifitasan pemrosesan surat khususnya distribusi surat masuk dimulai dari diterimanya surat sampai dengan proses penyelesaian maksud dan tujuan dari surat tersebut dengan membandingkan sebelum pemanfaatan atau tata persuratan secara manual dengan setelah pemanfaatan tata persuratan menggunakan paperless office system.

\subsection{Analisis sebelum pemanfaatan paperless office system}

Berdasarkan standar proses sebuah surat masuk ke instansi Universitas Islam Negeri Raden Fatah Palembang, dari awal surat di terima di bagian administrasi tata usaha, di agendakan pada buku kendali kemudian diteruskan ke pimpinan sesuai tujuan surat sampai dengan proses penyelesaian akhir maksud dan tujuan surat akan membutuhkan waktu yang tidak bisa di pastikan atau dapat memakan waktu berhari-hari menyebabkan layanan terhadap stakeholder menjadi sering terhambat. Permasalahan seringnya keterhambatan inilah menjadi serius ketika suatu instansi pelayanan publik tidak dapat memberikan kepastian layanan. Kendala yang di hadapi oleh Universitas Islam Negeri Raden Fatah Palembang selama ini, antara lain:

1) Pemrosesan surat masuk sangat tergantung pada kehadiran pimpinan, kehadiran pimpinan merupakan faktor utama dalam pemberian layanan dalam memberikan perintah, dimulai dari pimpinan tertinggi maupun pimpinan setingkat di bawahnya atau pegawai penerima perintah surat. Sebuah surat tidak bisa di proses sampai dengan kehadiran pimpinan di ruang kerjanya.

2) Jam kerja yang sangat terbatas dengan hanya tujuh setengah jam dalam sehari membuat tingkat efektifitas pemrosesan surat menjadi sedikit yang pastinya akan berdampak pada penyelesaian pekerjaan atau pemberian layanan kepada stakeholder.

Sehingga dengan sistem konvensional atau sistem manual seperti ini akan menghambat jalannya layanan administrasi dan berdampak pada ketidak puasan serta menimbulkan asumsi negatif bagi publik terhadap layanan pada Universitas Islam Negeri Raden Fatah Palembang.

\subsection{Analisis setelah pemanfaatan paperless office system}

Universitas Islam Negeri (UIN) Raden Fatah Palembang mulai memanfaatkan teknologi informasi tata persuratan surat masuk berbasis online atau paperless office system ini sejak Mei 2019. Semua surat masuk ke UIN Raden Fatah Palembang diinput ke dalam sistem melalui sub bagian tata usaha di Rektorat dan sub bagian umum di fakultas. Banyak permasalahan yang dihadapi dalam penerapan paperless office system, antara lain: masih adanya kekurangpahaman pegawai terhadap penggunaan teknologi informasi, jaringan internet yang belum merata, kurang pahamnya terhadap alur bisnis proses dari suatu paperless office system ini.

Pemanfaatan paperless office system sangat dirasakan manfaatnya. Pelayanan kepada publik dapat diselesai tanpa tergantung dari kehadiran pimpinan, pimpinan dapat menginstruksikan atau mendisposisikan surat masuk dimanapun pimpinan berada tanpa di batasi oleh tempat dan waktu. Pimpinan dapat mendisposisi surat saat di luar jam kerja maupun di hari libur. Hal ini dapat dilihat dari data waktu pemrosesan surat tanpa mengabaikan tata kelola administrasi pemerintahan. 


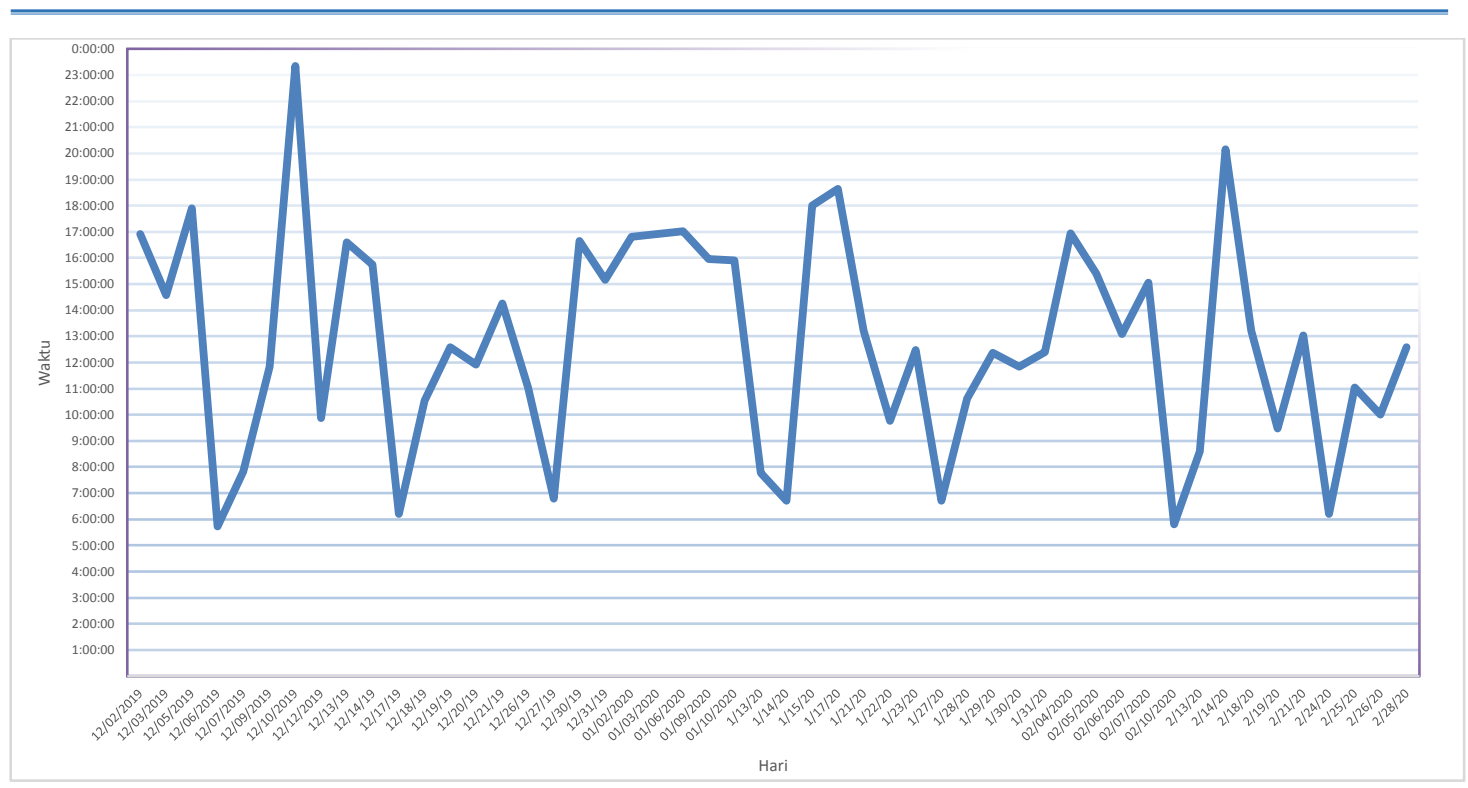

Gambar 3 Grafik Waktu Pemrosesan Surat

Data waktu pemanfaatan paperless office system ini di ambil dari bulan Desember 2019, Januari 2020 dan Februari 2020. Dari grafik waktu tersebut, di bulan Desember 2019 dalam 20 hari kerja surat masuk 695 surat dengan rata-rata surat masuk per-hari 34,75 surat. Surat yang diselesaikan atau di disposisi oleh pimpinan dalam jam kerja berjumlah 239 surat dan 456 surat diselesaikan pimpinan di luar jam kerja, artinya $65,61 \%$ surat diselesaikan di luar jam kerja. Bulan Januari 2020 dalam 23 hari kerja surat masuk 585 surat dengan rata-rata surat masuk per-hari 25,43 surat. Surat yang diselesaikan atau di disposisi oleh pimpinan dalam jam kerja berjumlah 239 surat dan 346 surat di selesaikan pimpinan di luar jam kerja, artinya 59,15\% surat diselesaikan di luar jam kerja. Dan, di bulan Februari 2020 dalam 20 hari kerja surat masuk 552 surat dengan rata-rata surat masuk per-hari 27,60 surat. Surat yang diselesaikan atau di disposisi oleh pimpinan dalam jam kerja berjumlah 136 surat dan 416 surat di selesaikan pimpinan di luar jam kerja, artinya 75,36\% surat diselesaikan di luar jam kerja.

Tabel 1 Pemanfaatan Paperless Office System

\begin{tabular}{clcccccc}
\hline No. & Uraian & $\begin{array}{c}\text { Penyelesaian } \\
\text { per bulan }\end{array}$ & $\begin{array}{c}\text { Hari } \\
\text { Kerja }\end{array}$ & $\begin{array}{c}\text { Rata- } \\
\text { rata } \\
\text { perhari }\end{array}$ & $\begin{array}{c}\text { dalam } \\
\text { Kerja }\end{array}$ & $\begin{array}{c}\text { luar } \\
\text { jam } \\
\text { kerja }\end{array}$ & $\begin{array}{c}\text { persentase di } \\
\text { luar jam } \\
\text { kerja }\end{array}$ \\
\hline 1 & $\begin{array}{l}\text { Desember } \\
2019\end{array}$ & 695 & 20 & 34,75 & 239 & 456 & 65,61 \\
\hline 2 & Januari 2020 & 585 & 23 & 25,43 & 239 & 346 & 59,15 \\
\hline 3 & $\begin{array}{l}\text { Pebruari } \\
2020\end{array}$ & 552 & 20 & 27,60 & 136 & 416 & 75,36 \\
\hline
\end{tabular}

Berdasarkan hasil penelitian yang diperoleh dari data aplikasi e-office Universitas Islam Negeri Raden Fatah Palembang, rektor dapat menyelesaikan banyak surat yang diterima dalam waktu saat di luar jam kerja. Pemanfaatan teknologi informasi dan komunikasi merupakan suatu hal yang sangatlah penting, ini dikarenakan bahwa suatu teknologi informasi dan komunikasi dapat meningkatkan efektifitas dan efisiensi layanan instansi Universitas Islam Negeri Raden Fatah Palembang terhadap publik dalam memberikan layanan. Manfaat yang ditimbulkan dari pemanfaatan paperless office system ini, antara lain:

1) Banyaknya surat yang dapat di baca atau diproses oleh pimpinan.

2) Lebih dari $50 \%$ surat dapat di proses di luar jam kerja.

3) Tidak adanya penumpukan berkas surat di meja kerja pimpinan.

4) Tidak terhambatnya pemberian pelayanan administrasi perkantoran kepada publik. 
Kepercayaan masyarakat terhadap lembaga Universitas Islam Negeri Raden Fatah Palembang tetap terjaga.

\section{KESIMPULAN}

Hasil dari penelitian ini dapat disimpulkan, bahwa pemanfaatan teknologi informasi dan komunikasi tata persuratan (paperless office system) di Universitas Islam Negeri Raden Fatah Palembang khususnya pemrosesan surat masuk sudah berjalan lancar dan sangat efektif. Dengan efektifitasnya dari pemanfaatan paperless office system ini, memberikan dampak terhadap tata persuratan UIN Raden Fatah Palembang semakin baik, kemudahan dalam pencarian arsip, tidak terhambatnya pemberian layanan administrasi perkantoran kepada stakeholder, serta tingkat kepercayaan masyarakat terhadap lembaga Universitas Islam Negeri Raden Fatah Palembang tetap terjaga.

\section{DAFTAR RUJUKAN}

Herdiana, F., \& Marsofiyati. (2019). Penerapan dan Pemanfaatan E-Office sebagai perwujudan paperless office. Informasi Dan Komunikasi, 3(1), 74.

Khairil. (2012). Implementasi Pengamanan Database menggunakan MD5. 8(1), 29-44.

Muhadjir, N. (1996). Metodologi Penelitian Kualitatif. Rake Sarasin.

Mulyono, T. (2018). Sistem Informasi E-Office Pendukung Program Paperless Korespondensi

Perkantoran ( Studi Kasus : Bagian Administrasi Akademik Akademi Komunitas Semen Indonesia Gresik ). Tecnoscienza, 2(2), 108-122.

Nurhadi, Z. F., \& Kurniawan, A. W. (2017). Kajian Tentang Efektifitas Pesan Dalam Komunikasi. Jurnal Komunikasi Hasil Pemikiran Dan Penelitian-ISSN, 1, 90-95. https://journal.uniga.ac.id/index.php/JK/article/view/253

Parsaorantua, P. H. P., Pasoreh, Y., \& Rondonuwu, S. A. (2017). Implementasi Teknologi Informasi Dan Komunikasi (Studi Tentang Web E-Government Di Kominfo Kota Manado). Acta Diurna, VI(3).

Reja, I., \& Suban, A. L. (2016). Analisis Penerapan dan Optimalisasi Sistem Informasi

Sekolah Terpadu ( SisTer) Sebagai perwujudan Paperless Administration Menuju Sekolah Berbasis E-Document. Senapati.

Sugiarto, A., \& Wahyono, T. (2014). Manajemen Kearsipan Elektronik. Gava Media.

Sugiyono. (2013). Metode penelitian pendidikan:(pendekatan kuantitatif, kualitatif dan $R \&$ D). Alfabeta.

Sulistiyono, M., \& Yasin, F. (2016). Pemanfaatan Paperless Office System Dalam EGoverment Studi Kasus Kementrian Pendidikan Dan Kebudayaan. Jurnal Teknologi Informasi, XI(31), 1-9.

Supriyanto, E. E. (2016). Kebijakan Inovasi Teknologi Informasi (IT) Melalui Program

Elektronik Goverment dalam Meningkatkan Kualitas Pelayanan Publik di Indonesia. 
54 JUSIFO (Jurnal Sistem Informasi), p-ISSN: 2460-092X, e-ISSN: 2623-1662

Jurnal Ilmu Pemerintahan: Kajian Ilmu Pemerintahan Dan Politik Daerah, 1(1), 141. https://doi.org/10.24905/jip.v1i1.438 